\title{
Changing ownership structures in the water supply and
}

\section{sanitation sector}

The development over time of the water supply and sanitation sectors in four countries is analysed to reveal the changing role of the private sector. In some cases, local small-scale private water supply and sanitation systems have been able to develop progressively into large-scale official systems, which may later be privatised. In other cases, foreign capital has been more significant in the development of modern water supply and sanitation systems, particularly where privatisation has occurred much earlier in the national development process. In much of the developing world, domestic water supply and sanitation is dominated not by the official water supply and sanitation companies but by independent operators who function without subsidies but with enormous variability in terms of quality of service and prices offered. In general they are constrained, however, by the absence of appropriate institutional and legal frameworks, including the lack of independent regulatory authorities. There is a need, where appropriate, to continue to encourage large-scale private sector involvement in the official water supply sectors of the developing world. At the same time though, it is only by promoting policies that also further the development (where appropriate) of the independent water supply and sanitation providers that access to water supply and sanitation services can be maximised since better use of local resources in many developing countries, both local human resources and capital, provide a key means for improving access to water supply and sanitation.

Key words: water supply, sanitation, privatisation, independent operators.

\section{Introduction}

Eighty-two per cent of the population of the world, or 4.9 billion people, have access to basic safe water supplies, and only 60 per cent, or 3.6 billion people, have access to basic sanitation facilities (WHO / UNICEF Joint Monitoring Programme for Water Supply and Sanitation, 2000). While approximately 816 million additional people gained access to water supply 
services and 747 million to sanitation services between 1990 and 2000, the percentage increase in coverage was modest against the background of rapid global population growth over the same period. The nature of the problem is compounded by the fact that there is significant population growth, particularly in urban areas, while there has been a tendency towards under-investment in the infrastructure needed for water provision (Sinclair, 2000, p355).

At the United Nations Millennium Summit in 2000 a target was set to halve the proportion of people without access to safe drinking water as part of the Millennium Development Goals. At the World Summit on Sustainable Development in Johannesburg this target was extended to also include halving the proportion of people without access to basic sanitation (United Nations Commission on Sustainable Development, 2002, paragraph 7). With global population likely to exceed 7 billion people by 2015 (United Nations Population Division, 2002), this commitment will pose formidable challenges since it involves not only maintaining existing levels of supply, but also providing new or upgraded water services to approximately 1.7 billion and sanitation access to a further 2.1 billion people.

In recent years there has been a growing trend towards privatisation of publicly owned water supply and sanitation services in much of the world. There has been a shift away from seeing water as a public good that is essential for life with subsidies being required as part of an overall welfare system. Policies promoting geographic equalisation have lost favour as have policies basing water tariffs on rateable property values rather than metered water use (Bakker, 2001, p144). A more market orientated approach has been adopted where the state is still seen as being critical to ensuring that universal access to water supply and sanitation services are maintained but where market forces can be used to meet this aim (Haugton, 2002, 
p793). In the West this shift has been led by the neo-liberalist drive to reduce state spending and taxes while simultaneously increasing investment in the water sector, while in the developing world the World Bank has promoted neo-liberal reforms in the water sector as a means to free up state expenditures for other social priorities, rather than as a means to reduce taxation (Haugton, 2002, p793). Some form of well regulated privatisation is now seen by many as providing the cheapest means of maintaining and extending water supply and sanitation systems at the least political cost, thus leading to a rapidly growing global market for private water management services (Haugton, 2002, p794).

Motivations for privatisation of state owned industry sectors vary. Parker (1998) notes that in addition to the belief that privatisation leads to efficiency gains, other motivations for privatisation have included the promotion of the national capital market, increasing stock market capitalisation, government financing to reduce debt, and as a means of attracting new investors or investment. To these rationales, Cook (1998) adds enhancing freedom of choice and weakening trade unions. Meek (1998, p100) argues that the goal of increasing efficiency through competition has not always been the primary goal of utility privatisation policies.

Privatisation of government owned utilities was until recently more limited in developing countries than developed countries due to a variety of reasons. Reasons included the technically difficult nature of privatisation processes, unfavourable local economic conditions, opposition from powerful vested interests, and the mix of economic and noneconomic goals that many public enterprises fulfil that private enterprises were seen as unlikely to adopt (Young, 1995, p163). Economic difficulties together with pressure from multilateral financial institutions have led to major reassessments of the role that government 
now plays in the delivery of services such as water supply and sanitation that were once considered to be the realm of government.

This paper asks how the role of the private sector in the water and sanitation industry has changed over time and how it varies in different socio-economic and geographic contexts. This question is important for addressing how different ownership structures can be used to maximise development in the water and sanitation sector by revealing which ownership structures, if any, are most appropriate for a given setting. Therefore, development over time of the water and sanitation sector in a range of countries will be analysed to reveal the changing role of the private sector, as well as how the perceived role of the private sector in this area has changed.

The four case studies chosen are all countries where some degree of privatisation of the water supply and sanitation sectors has been introduced, and hence there exists a significant body of literature reviewing what process occurred or is still occurring, the roles of the different actors, and the effects of the privatisation process. The countries studied are Britain, Argentina, Côte d'Ivoire and Israel.

In the literature on water supply and sanitation sector a distinction is frequently drawn between formal (official) water supply systems and the water supply services provided by operators acting in a supplementary role to the formal system. The official water supply authorities frequently have monopoly rights to water supply services within their area of jurisdiction while the other operators frequently operate without any official legal sanction and in some cases illegally. Such independent operators are frequently described in negative terms by the literature. For example, a recent World Bank report on the water sector stated 
that in "city after city in the developing world the unserved poor pay ten or more times the price for a liter of water than is paid by their fellow citizens who are served with formal supplies" (World Bank, 2002b, p6). However, more realistically, there is enormous variability in terms of quality of service and prices offered by independent water and sanitation providers (Solo, 1999, p122). As part of the question of how the role of the private sector in the water and sanitation industry has changed over time this paper seeks to examine the extent to which the distinction between official and independent water supply and sanitation providers is valid.

\section{Development of water supply and sanitation sector}

\section{England and Wales}

The water supply and sanitation sector in England and Wales has evolved through a series of stages over a very long period of time, beginning as a predominantly private run system and eventually returning to private control. During the nineteenth century the water and sanitation industry developed as a mixture of municipal and small private undertakings (Saal and Parker, 2001, p64). According to Hassan (1998) arms length government regulation of the industry during mid-Victorian times was a failure, with many private water companies unwilling to expand their operations where profits were doubtful; government generally treated water supply as a natural monopoly. Because of the problems resulting from privately owned supply systems, municipal services increasingly began to dominate by the end of the nineteenth century (Hassan, 1998, p18). This was because private companies at that time lacked the resources to build water supply systems on the scale of those completed by municipalities, and local government had an advantage at this time in obtaining cheap finance (Hassan, 1998, 
p19). Effective sewage disposal developed more slowly than water supply systems over the course of the nineteenth century.

Unlike other utilities such as electricity and gas, no national grid for either water or sewage services emerged but consolidation still occurred over time and there were some attempts at increasing regulation during the first half of the twentieth century (Hassan, 1998, Sawkins, 2001, p190). Between the 1950s and 1970 the number of water undertakings in Britain fell from more than 1,000 to around 200, due to mergers (Hassan, 1998, p92). In 1974, however, the British government took control of what was still a fairly fragmented system and created ten regional water authorities that were given full responsibility for the entire water cycle within their catchment areas (Saal and Parker, 2001, p65). This was the culmination of attempts to establish the integrated management of water resources in England and Wales (Hassan, 1998, p126). In addition, 29 private statutory companies were permitted to continue their operations of supplying water only, with sewage services in the areas they served to be supplied by the local regional water authority.

According to Bakker (2001, p144) prior to the nationalisation of 1974, security of supply and public health were the priorities of water supply management. Public ownership and subsidies had been adopted as management principles at the beginning of the twentieth century, with water users expected to pay according to their ability to pay rather than the costs they imposed on the system (Bakker, 2001). Water was regarded as a strategic resource.

The reorganisation of the water industry of 1974 moved the industry from consisting of a patchwork of local municipal systems to an industry functioning at the regional scale that was combined with a strong national framework for investment and research (While and 
Haughton, 2001, p723). One of the drawbacks of the new structure was the difficulty of meeting new investment needs from central funding sources, placing the system under strain, particularly due to the public expenditure cuts of the 1970 s and the need to renew deteriorating infrastructure (While and Haughton, 2001, p723). While many efficiency measures were introduced into the water industry throughout the 1980s, including job shedding and cost-benefit analysis for investment, it was privatisation that consolidated the earlier transformations and completed the reform process (Bakker, 2001, p144).

In 1989 the regional water authorities were privatised and became publicly listed water and sewage companies and the 29 statutory water companies were transformed into normal public limited liability companies (Saal and Parker, 2001, p65). While privatisation was inline with neo-liberal policies that saw the state as a less efficient provider of services than private industry, it allowed the state to reduce its liabilities and level of direct control while facilitating new sources of investment and expertise (While and Haughton, 2001, p723). A new regulatory body was created as it was not felt appropriate to leave responsibility for regulating their own water quality with the new private companies, and the industry's debt of $£ 4.95$ billion was written off (Saal and Parker, 2001, p65). Previously publicly owned utilities were floated intact on the stock market, creating large private monopolies organised at the catchment scale (Bakker, 2001, p145).

There was a fundamental shift away from vertically integrated monopoly networks to new models of network management (Marvin, et al., 1999) and water supplies were opened up to limited cross border competition (Saal and Parker, 2001, p62). Comparative competition, however, was the primary means of introducing competition into the privatised water sector; the newly created regulator would monitor and publish the performance of individual 
companies, using the performance of the most efficient companies to set the standards for other companies to follow (Sawkins, 2001).

Water charges increased significantly in order to pay for the new investment required to meet higher European environmental standards and to pay for new infrastructure, with average bills increasing by as much as 50 percent with some companies (Marvin, et al., 1999, p118). Price rises since privatisation were well above inflation and are expected to continue rising with inflation (Bakker, 2001, p157).

An overall assessment of the effects of privatisation on the water and sanitation systems of England and Wales produces mixed results. Saal and Parker (2001), for example, argue that although productivity growth occurred, averaged across the industry as a whole growth did not improve relative to pre-privatisation. Sawkins (2001, p213) argues that despite the reforms since privatisation the water industry in England and Wales remains highly regulated and difficult for new players to enter. Some of the less politically acceptable aspects of privatisation have been mitigated through government intervention (Bakker, 2001, p158). While initial consumer support for privatisation of water and sanitation services was low, as the industry has matured following privatisation, general acceptance of a privatised industry has slowly increased. In part this acceptance may be due to the fact that the privatisation of the industry is now fully established and unlikely to be changed in the foreseeable future.

The benefits directly accruing to British consumers as a result of privatisation may have been modest, however, the privatisation of the industry has made the privatised water companies well placed to take advantage of the expanding global opportunities in the water and sanitation sectors. At the same time some British water and sanitation companies have merged 
or been taken over by other global water corporations. Thames Water, for example, merged in 2000 with RWE, a Germany based utilities company and is now responsible for the management of the company's global water business (Thames Water, 2003). Only 13 million of Thames Water's 69 million customers are located in the UK, meaning that the company has a significant global presence.

\section{Argentina}

Almost a third of Argentina's population of 37 million is concentrated in Buenos Aires and its surrounding suburbs. The central core of the city, the Federal District, is surrounded by 30 other districts (Hardoy and Schusterman, 2000, p64). Buenos Aires is located on the west bank of the Rio de la Plata River which supplies 92 percent of the city's needs, with marginal water supply costs being very low (Alcazar, et al., 2001, p3). Water scarcity is not reflected in the tariffs paid by consumers in Buenos Aires due to the plentiful water supply available to the city, rather, tariffs reflect water treatments costs and the costs of managing the distribution network (Mazzucchelli, et al., 2001, p87).

Obras Sanitarias de la Nación (OSN) functioned from 1870 until 1980 as the national water and sanitation supplier of Argentina but in 1980 the jurisdiction of the company was limited to the city of Buenos Aires and the 13 surrounding districts (Conte Grand, 1998, p4). With the exception of Buenos Aires, water supply and sanitation was devolved to the provincial authorities (Nickson, 2001, p1). Expansion of OSN's water network in Buenos Aires continued until the 1970s but expansion ended sharply in the 1980s due to a reduction in the company's revenues, a lack of qualified personnel and low levels of investment (Conte Grand, 1998, p5). Investment by OSN was insufficient to even maintain existing assets, leading to deterioration of the system at this time (Alcazar, et al., 2001, p4). OSN lacked 
separation from the rest of the public sector; it was not autonomous in its finances and the managers of OSN were responsible to the National Ministry of Economy and Public Works (Mazzucchelli, et al., 2001, p55).

In 1989 Argentina embarked on a major period of economic reform during which nearly all publicly owned utilities were either sold or transferred to private sector management (Loftus and McDonald, 2001, p179). Major economic reform became politically feasible at this time because Argentina's economic crisis encouraged co-operation after years of bitter political conflict (Alcazar, et al., 2001). In December 1992 Aguas Argentinas was awarded a 30 year concession to run Buenos Aires' water and sanitation network, with the company taking control of the network in May 1993 (Alcazar, et al., 2001). Aguas Argentinas was a consortium formed by local and international groups, with Suez Lyonnaise des Eaux, a French company, being the lead partner. The concession was awarded on the basis of the lowest tariff bid and included the requirement for the water supply and sanitation network coverage to be extended over the course of the concession, thus requiring substantial investment by the concessionaire. An independent regulatory agency was established by the government to monitor quality of service and ensure compliance with the contractual arrangements (Loftus and McDonald, 2001, p187).

Despite a plentiful supply of raw water, only 70 percent of the population within the metropolitan area of Buenos Aires were connected to the water supply system and 58 percent to the sewage system prior to the concession being established (Alcazar, et al., 2001, p20). This low rate of connection resulted from the lack of investment by OSN (Mazzucchelli, et al., 2001, p 95). In the poorer suburban areas of the city connection rates were much lower than the overall metropolitan area where only 55 percent of the population were connected to 
the water supply system and 35 percent to the sewage system (Zerah, 2001, p6). By 1997 coverage of the water supply system had reached 83 percent of the population (Alcazar, et al., 2001, p42). At the end of 2000, an additional 1.98 million people were connected to the water supply network, up from 5.76 million at the start of the concession, and 1.16 million additional people were connected to the sewage network, up from 4.66 million (Aguas Argentinas, 2001, p11). In addition, the existing water and sanitation network was rehabilitated since much was on the verge of collapse (Mazzucchelli, et al., 2001, p106).

Ninety-five percent of the population not connected to the official water supply network were dependent on shallow wells, a water source liable to pollution from the cesspools and septic tanks in widespread use in areas not connected to the sewage system (Alcazar, et al., 2001, p20). These wells represented a significant sunk investment on the part of their owners, thus many of the city's residents who could afford the access charges for connecting to the expanded official water supply and sanitation network resented the fact that they were required to connect to the network because their existing water supply and sewage systems were now outlawed (Alcazar, et al., 2001, p20).

Despite the network expansion carried out by Aguas Argentinas, the Buenos Aires water concession has had a number of difficulties, such as the privatised company finding the costs of connecting poorer districts of the city up to the water network being higher than originally expected and thus demanding that the contract be renegotiated, and rumours of corruption (Loftus and McDonald, 2001). These difficulties may be due, to some extent, to the fact that much of the information upon which the tender process was based was of poor quality (Alcazar, et al., 2001, p20). There have been a number of revisions to the initial concession 
contract, the first being in 1994 when the concessionaire was permitted a 13.4 percent tariff increase, approximately half the initial tariff reduction introduced when the concession was awarded (Zerah, 2001, p5). As a result of further revisions agreed in 1997, which increased average monthly bills for existing network users and decreased bills for new users, fundamental changes were made to the concession contract which meant that the concessionaire would then be paid in advance for network expansion (Zerah, 2001, p6). This prepayment system thus gave the concessionaire an incentive to delay investment as long as possible (Loftus and McDonald, 2001). A weak regulator combined with an ambitious network expansion targets thus resulted what has been described by some commentators as a regulatory failure (Zerah, 2001, p6).

There has been a significant amount written in the literature about the privatisation of Buenos Aires water and sanitation network. Alcazar et al (2001, p42) note that the network's privatisation led to a significant increase in investment and rise in the percentage of the population connected, with this investment being largely financed through increased debt. They calculate that as a result of the concession, collectively consumers in Buenos Aires are better off by \$US 1.33 billion, noting that this is a conservative estimate since certain benefits of privatisation were ignored in their calculations (Alcazar, et al., 2001, p51). Loftus and McDonald (2001), however, argue that the majority of the negative impacts of the concession have been felt by poorest neighbourhoods of Buenos Aires. Similarly Zerah (2001) concludes that the benefits of the Buenos Aires Concession accrued largely to the high and middle income users already connected at the time the contract was awarded with affordability of access for the poor being a key problem. Loftus and McDonald (2001) argue that although investment increased after the introduction of the concession, this investment was funded through higher surcharges and increased debt burdens, with the publicly owned water 
authority likely to have been able to achieve similar results since these finance sources would also have been accessible to the publicly owned authority (Loftus and McDonald, 2001, p189).

Many other provincial governments followed the example set by Argentina's national government and also privatised their own water utilities (Conte Grand, 1998). For example, in 1997 the Provincial government of Córdoba signed a 30 year concession with the Aguas Cordobesas, a private sector consortium headed by Suez-Lyonnaise des Eaux (Nickson, 2001, p1). The Córdoba concession contract is for the water supply of the Municipality of Córdoba, an area with a population of 1.4 million people (Nickson, 2001). At the time of the concession 83 percent of the population was connected to the official water supply network, with the concession contract requiring that coverage be increased to 97 percent by the end of the concession (Nickson, 2001, p1). A significant proportion of those not currently connected to the official water supply network were supplied by independent private providers who frequently sourced their water from local wells of low quality (Nickson, 2001, p1).

Similar to Córdoba, in 1999 the Azurix Corporation obtained 30 year water and sanitation services concessions for two regions within the province of Buenos Aires which included the provincial capital of La Plata and the city of Bahia Blanca (KPMG, 2002).

\section{Côte d'Ivoire}

Côte d'Ivoire does not face scarcity of water resources, with only 0.17 percent of available resources currently being used to meet domestic and industrial demand (N'Gbo, 2001).

In 1959, even before the independence of Côte d'Ivoire, an international tender was launched in order to select a private operator to run the water supply network of in the Côte d'Ivoire 
capital Abidjan (Kerf, 2000, p5). Before that time, water supply services had been the responsibility of municipalities which suffered from a lack of technical and financial resources that hindered efficient network operation and expansion (Kerf, 2000), and only 18 communities had formal water supply systems in place (N'Gbo, 2001, p192).

The Abidjan tender was won by French company, SAUR, who formed a new company with majority Côte d'Ivoire ownership but SAUR control in order to comply with the conditions of the tender contract (Menard and Clarke, 2000, p3). The new company, Société de Distribution d'Eau de Côte d'Ivoire (SODECI) had its role in Abidjan reduced in 1967 when the government took responsibility for the investment in the system while leaving operation and maintenance with SODECI (Menard and Clarke, 2000). However, in 1974 due to SODECI's success in Abidjan, its jurisdiction was expanded to include a fifteen year contract for the operation and maintenance of urban water supplies in all other Côte d'Ivoire cities (Menard and Clarke, 2000, p4). In parallel to this, management of the water sector in Côte d'Ivoire was transferred from municipalities to the central government, and a government agency was given ownership of assets, responsibility for investment, and management of the contact with SODECI (Kerf, 2000, p5, Menard and Clarke, 2000, p4). Finance in the water sector was given to an autonomous agency with borrowing power that received the difference between the water tariffs charged and SODECI's operator fees (Kerf, 2000). As a result of SODECI's jurisdiction being all urban areas in Côte d'Ivoire, profits earned in prosperous areas of Abidjan are used to subsidise operations in Côte d'Ivoire's towns (Collignon and Vézina, 2001).

In the 1980s Côte d'Ivoire faced serious economic difficulties which caused investment in its urban water sector to cease by 1985 (Kerf, 2000, p5). This economic crisis led to the reform 
of the sector, with the government transferring sector planning to SODECI while at the same time removing guaranteed revenues for the company where demand did not match forecasts following network extensions (Kerf, 2000, p7).

There has been a lack of competition in the water sector in Côte d'Ivoire. Bidding has been eliminated for most investment and renewal of the concessionary contract in 1988 took place without bidding (Menard and Clarke, 2000, p41). Efficiency gains likely to result from competition are absent and, while SODECI performs well by regional standards but still has high prices compared to Latin American and Asia, it is difficult to assess whether water might be able to be provided at lower cost in Côte d'Ivoire (Menard and Clarke, 2000, p41). Sewage services have always been separate from water supply in Abidjan which may have hampered the success of the water supply system (Menard and Clarke, 2000, p9, 36).

Today more than 400 localities are served by SODECI, and the number of connections to its networks has grown from 4,000 to 380,000 and serve a population of 6.5 million (Programme Solidarité Eau, 2002). There are currently more than 30,000 new connections per year and the key management positions in the company are all filled by Côte d'Ivoire nationals (Programme Solidarité Eau, 2002). Despite the urban population rising from 4.7 million in 1990 to 6.9 million in 2000, the percentage of the urban Côte d'Ivoire population served by water supply networks increased from 89 to 90 percent, and water is generally available 24 hours a day in urban areas (World Health Organisation, 2000).

Despite the general success of SODECI in developing Abidjan's water supply system, 22 percent of households receive their water from independent providers or traditional sources (Collignon and Vézina, 2001, p5). This is a figure far lower than many African cities where as 
much as 80 percent of the population may be dependent on such sources. Many of these independent providers operate with the sanction of SODECI; tank operators pay a fixed price for refilling their tanks from one of 500 public standpoints that SODECI controls around the city and then sell the water on to consumers, providing services such as home delivery (Solo, 1999, p123). While prices charged per unit of water may be high compared to SODECI's prices, such consumers don't have to pay fixed costs (N'Gbo, 2001, p205). In addition to this, SODECI has installed commercial water connections to residents living in officially authorised neighbourhoods of Abidjan located adjacent to areas of unauthorised settlement, knowing that the water will be resold by unofficial water vendors into these settlements (Collignon and Vézina, 2001, p13). Such water vendors frequently develop extensive piped distribution networks to facilitate this water resale (Collignon and Vézina, 2001, p13).

Côte d'Ivoire is relatively unusual compared to most African countries, as generally privatisation is not yet widespread in the region. According to Estache and Kouassi (2002, p4) in the period 1995-97 only two of 21 water utilities in Africa that they assessed had private sector participation, with one of these being the SODECI in Côte d'Ivoire. However, due to low proportion of the population that is served by many African water utilities, unofficial private sector participation in the water supply and sanitation sector is widespread. For example, in Bamako, Mali, the official water utility serves only 16 percent of households, and only two percent of households receive municipal sanitation services; independent water supply and sanitation providers hold the rest of the market (Collignon and Vézina, 2001, p13).

\section{Israel}

The current internationally recognised borders of Israel and its surrounding states were only agreed upon by the former colonial powers of the region, France and Britain in the 1920s, and 
the final borders between Israel and an emergent Palestinian state have yet to be agreed in a peace treaty.

In the pre-state period water laws varied from village to village, having developed by custom during the Ottoman period and continuing during the British Mandate, which ended in 1948 (Trottier, 1999). In this pre-state period, the Jewish community in Palestine undertook its own water network that linked the different Jewish settlements (Trottier, 1999). Because of the aridity of the land, water was seen by the Zionist movement as a potential impediment to settlement, hence the focus on developing water resources to permit settlement in the land (Feitelson, 2002, p299). The first large scale water project by the Zionist movement was built between 1935 and 1938 in the Jezreel valley in the north of the country by its newly established water company Mekorot (Sitton, 2000).

Following Israeli independence in 1948, Mekorot became Israel's government owned national water company. In 1959 a comprehensive water law was passed that did away with the private ownership of water throughout the country and placed all water resources under the direct control of the state and the state appointed Water Commissioner (Water Commission, 2002). In 1964 Israel's National Water Carrier was completed, interconnecting the different water resources of the country and permitting the large-scale conveyance of water from the relatively humid north of the country to the arid south.

At present Mekorot, as a government owned company, is responsible for managing the nation's water resources, including the wholesale supply of water to urban communities and industrial users. The company supplies approximately two-thirds of the total water used in Israel, with the remainder coming from privately owned facilities (Ministry of National 
Infrastructure, 2002). Water prices for the domestic, industrial and agricultural sectors differ from each other and are set centrally by the Ministers of National Infrastructures and Finance (Water Commission, 2002). Domestic and industrial users are supplied at full cost while agricultural water use in some areas is partially subsidised (Ministry of National Infrastructure, 2002). Municipalities are responsible for distributing water to individual domestic users.

Israel is moving towards privatisation and institutional reform of its water sector since it is seen that this will encourage greater efficiency in the sector and more rational use of water (Ministry of National Infrastructure, 2002). It is anticipated that new water suppliers will be carved out of Mekorot, with Mekorot's role then being limited to the operation of the National Water Carrier and its regional water supply schemes privatised (Ministry of National Infrastructure, 2002). Water prices will be determined by a market trading system and new water sources will be created by the building of desalination plants along the Mediterranean coast through private tenders. It is planned that municipalities will privatise the management of domestic water supply so that it will be carried out by independent profit-making companies (Ministry of National Infrastructure, 2002). Private tenders for the building and operation of major desalination plants along the Mediterranean coast have already been issued to Israeli and foreign companies (Israeli Ministry of Finance International Division, 2002).

The water supply network in the territory under the jurisdiction of the Palestinian Authority has some autonomy from the Israeli system. For example in the Gaza Strip where the majority of domestic water is supplied by municipalities, 70 to 80 percent of water is drawn from domestic wells and the rest comes from Israeli system (Trottier, 1999). Private operators independent of the municipal networks also exist. A private operator in the Jabalya Refugee 
Camp (in the northern Gaza Strip), for example, has drilled his own well and developed a distribution network independent of the municipal systems (Trottier, 1999). In other areas, similar arrangements exist.

In the southern West Bank where centralised piped supply systems are lacking, many villages depend upon water delivered by tanker truck. Approximately 150 Palestinian communities are without water distribution systems and must depend upon such sources for their water supplies, with the water sales persons sourcing their water from a variety of sources, including natural springs, official water network outlets, and private wells (Trottier, 1999, p122). While competition exists between water sales persons, informal local oligolopolies can exist which permit higher prices than would exist in a true free market situation. Due to the absence of regulation, water quality delivered by the water sales persons can vary considerably (Trottier, 1999).

\section{Discussion}

It is clear from the case studies above that there is a lot of diversity in the water sector in terms of management structures, as would be expected given the range of political and social systems present together with the differences in environmental conditions that effect the water industry. Nonetheless the increasing global trend to move towards greater participation by the private sector in the water industry is clearly illustrated in these cases.

In England and Wales the water sector moved from small scale private and municipal water and sewage services through to a fully nationalised system and then back to a privatised system. Unlike the small-scale private and municipal system of the mid-nineteenth century, this privatised system consisted of a relatively few very large-scale enterprises and thus bares 
few similarities to the earlier system. Whereas government intervention was originally called for because of the inability of private capital to meet the scale of investment required in the water sector (Hassan, 1998, p19), it was partly government unwillingness to continue to meet the large investment needs of the sector that led to privatisation (Haugton, 2002, p793); ideological factors were also influential. Local (and foreign) capital by the time of privatisation in 1989 had acquired the ability to manage capital and investments of the scale required for the large scale water and sewage systems then in place that would have been unthinkable in the mid-nineteenth century prior to the increasing government intervention that occurred during the interim. Despite this, the privatised British water companies themselves have not been immune from foreign ownership despite their own ability to compete in global water markets.

In Israel, as with England and Wales, as the Israeli government now moves towards the corporatisation and privatisation of the water and sanitation systems, local (and foreign) capital has also acquired the ability to manage capital and investments of the scale required which did not exist at the time the nationalised system was put in place. This ability of Israeli capital has been demonstrated by the recent franchise agreements signed by two consortia of Israeli companies to each build a desalination plant of 30 million cubic metres a year along Israel's Mediterranean coast, following an international tender (Israeli Ministry of Finance International Division, 2002).

In the case studies of Argentina and Côte d'Ivoire foreign capital interests played a much larger role in the privatisation processes, and particularly with the case of Côte d'Ivoire, privatisation occurred much earlier in the development process than occurred in England and Wales, or is now occurring in Israel. In Buenos Aires, five consortia pre-qualified for the 
bidding process, including two French led consortia, a Spanish led consortium, and a British led consortium, thus the bidding process was dominated by foreign capital. The winning consortium, Aguas Argentinas, was majority foreign owned, although 37 percent of shares were held by Argentine companies and ten percent by workers in the water company (Alcazar, et al., 2001, p20).

In the case of Abidjan in Côte d'Ivoire a French company won the tender. However, because a condition of the tender specified that the operator had to be majority owned by Ivoirian shareholders, the winning company was initially 46 percent owned by the French company SAUR (World Bank, 1977 as cited byMenard and Clarke, 2000, p3). The Ivoirian government held a five percent share, individual Ivoirian investors 45 percent, and individual French investors four percent. Given that SAUR was by far the largest single investor, the dominance of SODECI by foreign capital was clear. However, the foreign domination of privatised water and sanitation services does not necessarily mean an absence of local control or participation. In SODECI the President, Managing Director, all Operations Directors, and virtually all Technical Directors are Côte d'Ivoire nationals (Programme Solidarité Eau, 2002).

England and Wales, and Israel are considered to be developed high incomes countries by the World Bank (although the West Bank and Gaza are considered to be a lower-middle income developing economy) (World Bank, 2002a). Argentina and Côte d'Ivoire are both classed as severely indebted developing countries, Argentina as an upper-middle income country with a high level of human development, and Côte d'Ivoire as a low income country with a low level of human development (United Nations Development Programme, 2003, World Bank, 2002a). Per capita Gross Domestic Product (GDP) (purchasing power parity), at the time that the case study countries began their privatisations of their water supply and sanitation sectors, 
confirms that the classifications of the World Bank as remaining appropriate. In 2002 US dollar terms, Côte d'Ivoire had GDP per capita of \$1366 in 1959, compared to \$1490 in 2001 (Maddison, 1995, United Nations Development Programme, 2003). Similarly, in Argentina GDP per capita has risen from $\$ 10565$ to $\$ 11320$ between 1992 and 2001, while in Britain, GDP per capita has risen from \$22594 in 1989 to \$24160 in 2001 when measured in 2002 US dollars (Maddison, 1995, United Nations Development Programme, 2003). Israel's privatisation of its official water supply system has only just began.

It appears that in many less developed countries, local capital frequently lacks the resources or capacity to manage large-scale privatised networks, hence privatisation tends to lead to foreign investment and control. While this may raise questions of economic sovereignty in some countries, in itself it is not necessarily negative.

In the case of developing countries, global institutions such as the International Monetary Fund and the World Bank, promote their agenda of developing an international free market via their funding programmes in individual countries (Laurie and Marvin, 1999). The World Bank has been active in facilitating the commercialisation of public water utilities and the development of regulatory frameworks (Pitman, 2002, p25). For example, by the time the concession for Buenos Aires water and sanitation system was put in place in 1993 the World Bank and Inter-American Development Bank had both been involved in the sector for several years and assisted with the overall implementation of the process (Loftus and McDonald, 2001, p183). In its own assessment of its water strategy, the World Bank has acknowledged that getting the private sector to focus on the needs of the poor has been difficult when implementing privatisations in the water sector (Pitman, 2002). In particular, the urban 
periphery poses a major challenge to both the public and private water sectors, where supply can be difficult and the commercial risks too high.

In the case of Britain, it was the merger over time of small-scale local water or sanitation providers that produced the larger water companies, with the process being encouraged by the British government. In Palestine and later Israel what began as a relatively small private company eventually become the national water supply authority. In Argentina, but particularly in Côte d'Ivoire, independent water and sanitation providers still play a significant role in meeting the overall needs of the population.

It does not make sense to draw a sharp division between official and unofficial providers, or perhaps more significantly, to ignore unofficial providers when considering the water supply and sanitation sector. Particularly as the Côte d'Ivoire case study began to illustrate, in much of the developing world, domestic water supply and sanitation is dominated not by the officially sanctioned water and sanitation companies but by independent, frequently small scale, operators who may hold more than 80 percent of the water supply market (Collignon and Vézina, 2001, p50).

Collignon and Vézina (2001, p10) and Solo (1999, p123) note that independent operators deliver their services without any subsidies or monopolistic conditions, while official water and sanitation providers tend to focus upon the most profitable urban areas. Despite this, independent operators are expected to charge similar rates to those of the official providers. It is generally not a lack of equipment, appropriate technology or human resources that constrain independent operators, but rather the absence of an appropriate institutional and 
legal framework, including the lack of an independent regulatory authority (Collignon and Vézina, 2001, p50).

\section{Conclusions}

If the challenge set at the World Summit on Sustainable Development at Johannesburg in 2002 is to be met of halving by 2015 the proportion of people who are unable to reach or afford safe drinking water and the proportion of people who lack access to basic sanitation, then both the public and private sectors have major roles to play. Given the magnitude of the task at hand, innovative policy options need to be considered that maximise the contribution from all key players. This will include the continued development and expansion of large-scale water and sanitation schemes into regions of cities in the developing world where they are currently absent or inadequate. It will also need to include the development of policies that better ensure access by the poorer elements of society to large-scale city-wide schemes, whether they are provided by the public or private sectors, and local or foreign capital. This may be facilitated by greater service differentiation in order to better reflect variable household preferences and budgets (Johnstone and Wood, 2001, p48). However, given the high proportion of people in many developing cities that are currently unserved by official water and sanitation systems and the fact that rapid population growth for the most part will continue, there is a need to develop policies that also further the development (where appropriate) of the independent water and sanitation providers, giving them a degree of policy importance in policy development that matches their existing importance in meeting water supply needs. By recognising and introducing a degree of regulation of the activities of independent water and sanitation providers consumers dependent on their services stand to benefit (Johnstone and Wood, 2001, p48). 
International agencies should, where appropriate, continue to encourage private sector involvement in the official water sectors of the developing world. At the same time though, establishing suitable policy frameworks for independent water and sanitation providers that encourage investment and which lead to service improvements and cost reductions is equally important. Better use of local resources, both local human resources and capital, provide a key means for improving access to water and sanitation. In Britain it was the unregulated water industry of the nineteenth century made up of many small-scale independent and municipal suppliers that eventually developed into the globally active water companies of today. Similarly, in Palestine (later Israel), it was the small-scale water works of the Jewish community, rather than the Mandate government, that eventually developed into an efficient national system. Small scale and independent water and sanitation providers can have an important role to play in the development of a modern and efficient water sector. Maintaining a sharp distinction between independent providers and official government or privatised (frequently foreign controlled) water and sanitation networks is not helpful if targets of increasing access to water are to be met.

\section{Author Bios:}

Jonathan L. Chenoweth is a lecturer in the Centre for Environmental Strategy, University of Surrey, Guildford, Surrey, GU2 7XH, UK. Email: j.chenoweth@surrey.ac.uk. He graduated with a Ph.D. from the University of Melbourne in 2000 and has conducted research in Australia, south-east Asia, and the Middle East in the areas of environmental policy and water management. 


\section{References}

Aguas Argentinas. 2001. 1993-2000: We Build More, Looking Ahead. Buenos Aires:Aguas Argentinas.

Alcazar, L., Abdala, M. A. and Shirley, M. M. 2001. The Buenos Aires Water Concession. Washington D.C.:World Bank.

Bakker, K. J. 2001. "Paying for Water: Water Pricing and Equity in England and Wales." Transactions of the Institute of British Geographers 26, No. 2: 143-164.

Collignon, B. and Vézina, M. 2001. Independent Water and Sanitation Providers in African Cities. Washington D.C.:UNDP / World Bank Water and Sanitation Program.

Conte Grand, M. 1998. "Regulation of Water Distribution in Argentina." Twelfth Plenary Session of the OECD Advisory Group on Privatisation (AGP). ed. Helsinki: OECD.

Cook, P. 1998. "Privatisation in the Uk: Policy and Performance." In Privatisation in the European Union: Theory and Policy Perspectives. D. Parker, ed. London: Routledge.

Estache, A. and Kouassi, E. 2002. Sector Organization, Governance, and the Inefficiency of African Water Utilities. Washington D.C.:World Bank.

Feitelson, E. 2002. "Implications of Shifts in the Israeli Water Discourse for IsraeliPalestinian Water Negotiations." Political Geography 21, No. 293-318.

Hardoy, A. and Schusterman, R. 2000. "New Models for the Privatization of Water and Sanitation for the Urban Poor." Environment and Urbanization 12, No. 2: 63-75.

Hassan, J. 1998. A History of Water in Modern England and Wales. Manchester:Manchester University Press.

Haugton, G. 2002. "Market Making: Internationalisation and Global Water Markets." Environmental and Planning A 34, No. 791-807.

Israeli Ministry of Finance International Division. 2002. "Franchise Agreements Signed with the Winners of the First B.O.O. Tenders for Seawater Desalination." Israeli Ministry of Finance International Division. http://www.finance.gov.il/beinle/press67.htm Accessed: 3 January 2003

Johnstone, N. and Wood, L. 2001. "Water and Sanitation in Low Income Neighbourhoods: The Scope for Service Differentiation and Decentralised Management." In Private Firms and Public Water: Realising Social and Environmental Objectives in Developing Countries. N. Johnstone and L. Wood, ed. Cheltenham: Edward Elgar.

Kerf, M. 2000. Do State Holding Companies Facilitate Private Participation in the Water Sector? Evidence from Côte D'ivoire, the Gambia, Guinea, and Senegal. Washington D.C.:World Bank.

KPMG. 2002. "The Water and Wastewater Industry of Buenos Aires." KPMG. Final. http://www.superbuild.gov.on.ca/english/Study7-Vol2-Argentina\%20Water.pdf Accessed: 15 November 2002

Laurie, N. and Marvin, S. 1999. "Globalisation, Neoliberalism, and Negotiated Development in the Andes: Water Projects and Regional Identity in Cochabamba, Bolivia." Environment and Planning A 31, No. 1401-1415.

Loftus, A. J. and McDonald, D. A. 2001. "Of Liquid Dreams: A Political Ecology of Water Privatization in Buenos Aires." Environment and Urbanization 13, No. 2: 179-199.

Maddison, A. 1995. Monitoring the World Economy 1820-1992. Paris:OECD.

Marvin, S., Graham, S. and Guy, S. 1999. "Cities, Regions, and Privatised Utilities." Progress in Planning 51, No. 91-169. 
Mazzucchelli, S. A., Pardinas, M. R. and Tossi, M. G. 2001. "Private Sector Participation in Water Supply and Sanitation: Realising Social and Environmental Objectives in Buenos Aires." In Private Firms and Public Water: Realising Social and Environmental Objectives in Developing Countries. N. Johnstone and L. Wood, ed. Cheltenham: Edward Elgar.

Meek, C. 1998. "Privatisation Doesn't Necessarily Equal Competition: The Uk Experience." In Who Benefits from Privatisation? M. Hossain and J. Malbon, ed. London: Routledge.

Menard, C. and Clarke, G. 2000. Reforming Water Supply in Abidjan, Côte D'ivoire: A Mild Reform in a Turbulent Environment. Washington D.C.:World Bank.

Ministry of National Infrastructure. 2002. "The Water Sector." Ministry of National Infrastructure. http://www.mni.gov.il/english/units/water/water.shtml Accessed: 13 November

N'Gbo, A. G. M. 2001. "Private Sector Participation in Water Supply and Sanitation: Realising Social and Environmental Objectives in Abidjan." In Private Firms and Public Water: Realising Social and Environmental Objectives in Developing Countries. N. Johnstone and L. Wood, ed. Cheltenham: Edward Elgar.

Nickson, A. 2001. The Córdoba Water Concession in Argentina. London:GHK International.

Parker, D. 1998. "Privatisation in the European Union: An Overview." In Privatisation in the European Union: Theory and Policy Perspectives. D. Parker, ed. London: Routledge.

Pitman, G. K. 2002. "Bridging Troubled Waters: Assessing the World Bank Water Resources Strategy." World Bank Operatoins Evaluation Department. http://lnweb18.worldbank.org/OED/OEDDocLib.nsf/DocPgNmViewForJavaSearch/w ater_resource_strategy/\$file/water.pdf Accessed: 23 January 2003

Programme Solidarité Eau. 2002. "Côte D'ivoire Water Distribution Company (Sodeci)." Programme d'économie environmentale urbaine et populaire. http://www.globenet.org/preceup/pages/ang/chapitre/capitali/experien/coteivo.htm Accessed: 13 December 2002

Saal, D. S. and Parker, D. 2001. "Productivity and Price Performance in the Privatized Water and Sewerage Companies of England and Wales." Journal of Regulatory Economics 20, No. 1: 61-90.

Sawkins, J. W. 2001. "The Development of Competition in the English and Welsh Water and Sewerage Industry." Fiscal Studies 22, No. 2: 189-215.

Sinclair, I. C. 2000. "Better Laws = Better Environment: The Role of the Environmental Lawer in the Reconstruction and Modernisation of the Water Sector in Private Sector Participation." Water, Air and Soil Pollution 123, No. 353-360.

Sitton, D. 2000. "Development of Limited Water Resources: Historical and Technological Aspects." Applied Research Institutes, Ben-Gurion University of the Negev. http://www.mfa.gov.il/mfa/go.asp?MFAH0iae0 Accessed: 13 November

Solo, T. M. 1999. "Small-Scale Entreprenerus in the Urban Water and Sanitation Market." Environment and Urbanization 11, No. 1: 117-131.

Thames Water. 2003. "Thames Water." Thames Water. http://www.thames-water.com/ Accessed: 14 November

Trottier, J. 1999. Hydropolitics in the West Bank and Gaza Strip. Jerusalem:Palestinian Academic Society for the Study of International Affairs.

United Nations Commission on Sustainable Development. 2002. Plan of Implementation of the World Summit on Sustainable Development. Johannesburg:United Nations Commission on Sustainable Development.

United Nations Development Programme. 2003. Human Development Report 2003. New York:Oxford University Press. 
United Nations Population Division. 2002. World Population Prospects:The 2000 Revision: Volume Iii: Analytical Report. New York:United Nations.

Water Commission. 2002. "Israel's Water Economy." Ministry of National Infrastructures. http://www.mfa.gov.il/mfa/go.asp?MFAH0mb00 Accessed: 13 November

While, A. and Haughton, G. 2001. "Globalization, State Restructuring and Innovation in European Water Management Systems: Reflections from England and Wales." European Planning Studies 9, No. 6: 721-737.

WHO / UNICEF Joint Monitoring Programme for Water Supply and Sanitation. 2000. Global Water Supply and Sanitation Assessment 2000 Report. Washington:WHO ? UNICEF.

World Bank. 2002a. "Country Groups." World Bank. http://www.worldbank.org/data/countryclass/classgroups.htm Accessed: 15 September

World Bank. 2002b. "Water Resources Sector Strategy: Strategic Directions for World Bank Engagement: Draft for Discussion of March 25, 2002." World Bank. March 252002. http://lnweb18.worldbank.org/ESSD/essdext.nsf/18DocByUnid/C25233DD55DE1305 85256B8F007C8983?Opendocument Accessed: 21 January 2003

World Health Organisation. 2000. Water Supply \& Sanitation Sector Assessment 2000, Part 2. Brazzaville:World Health Organisation Regional Office for Africa.

Young, R. A. 1995. "Privatisation: An African Perspective." In Privatisation Policy and Performance: International Persepctives. P. Cook and C. Kirkpatrick, ed. Hemel Hempstead: Prentice Hall.

Zerah, M.-H. 2001. "The Buenos Aires Concession: The Private Sector Serving the Poor." Water and Sanitation Program. January 2001. http://www.wsp.org/pdfs/sa_buenos.pdf Accessed: 15 November 2002 